\title{
PENEGAKAN HUKUM TINDAK PIDANA KORUPSI YANG BERUPA PENERIMAAN GRATIFIKASI SEBAGAI SUAP
}

\begin{abstract}
Sunarto *
ABSTRACT

The phenomenon of gratification today is so endemic and leads to pathological symptoms, which is a condition in which corruption and gratification have been regarded as "limbs" and are no longer unlawful acts, because in addition to being done independently, corruption and gratification are often done in congregation. Whereas normatively, the regulation on corruption and gratification has been regulated in Law Number 20 Year 2001 concerning the Eradication of Corruption. From the surgical case that has been done can be explained that the increasingly rampant gratification of criminal settings in this country is set in Law No. 20 of 2001 on Corruption Eradication with the threat and maximum penalty of life and penalty of 1 billion rupiah, still less serious, less factual, and still limitative in nature, where the requirement for maximum sanction on the perpetrators of gratification crime proven by the court is considered difficult to be fulfilled, because it is based only on the condition of the occurrence of a momentum. From the Supreme Court's ruling it can also be drawn the understanding that the enactment of a life sentence against drug offenders is included because the crime has serious implications for the sustainability of life in society, so that if corruption is based on the same thing, similar to other special crimes. Law enforcement on bribery and gratification in Indonesia is relatively low, although Indonesia has had anti-gratification enforcement devices. However, the implementation of this regulation will still face several obstacles in terms of regulation, enforcement, and community perspective on money laundering crime. When viewed from the point of substance there is still a gap
\end{abstract}

Keywords: Acceptance of Gratification, Corruption Crime

\section{PENDAHULUAN}

Salah satu tindak pidana yang sangat fenomenal serta menjadi musuh seluruh bangsa adalah korupsi. Tindak pidana ini tidak hanya merugikan keuangan negara, tetapi juga merupakan pelanggaran terhadap hak-hak sosial dan ekonomi masyarakat. Korupsi merupakan persoalan klasik yang telah lama ada. Munculnya korupsi ketika orang mulai melakukan pemisahan antara keuangan pribadi dan keuangan umum. Pemisahan uang tersebut tidak ada dalam konsep kekuasaan

* Sunarto, Dosen Fakultas Hukum UNTAG Semarang, dapat dihubungi melalui email : dodi271100@gmail.com tradisional. Dengan kata lain korupsi mulai dikenal pada saat sistem politik modern berkembang.

Di berbagai belahan dunia, korupsi selalu mendapatkan perhatian yang lebih dibandingkan dengan tindak pidana lainnya. Fenomena ini dapat dimaklumi mengingat dampak negatif yang ditimbulkan oleh tindak pidana korupsi tersebut. Dampak yang ditimbulkan dapat menyentuh berbagai bidang kehidupan. Korupsi merupakan masalah serius, tindak pidana ini dapat membahayakan stabilitas dan keamanan masyarakat, membahayakan pembangunan nasional, sosial ekonomi, dan juga politik, serta dapat merusak nilai- 
nilai demokrasi dan moralitas karena lambat laun perbuatan ini seakan menjadi sebuah budaya. Korupsi merupakan ancaman terhadap cita-cita menuju masyarakat adil dan makmur. Korupsi secara yuridis dilukiskan dengan berbagai variasi di berbagai negara, namun masih ada titik persamaannya secara umum. Malaysia misalnya, memandang penyuapan sebagai korupsi yang sebenar nya, ditandai dengan nama komisinya "Badan Pencegahan Rasuah". "Rasuah" berasal dari bahasa Arab yang artinya suap.

Di Indonesia fenomena korupsi ini sudah ada sejak Indonesia belum merdeka. Pada masa penjajahan kolonial Belanda bentuk-bentuk kejahatan korupsi masih sangat sederhana, seperti terlihat dari perumusan pasal-pasal Kitab UndangUndang Hukum Pidana (KUHP), misalnya suap atau memaksa seseorang untuk memberikan sesuatu oleh pejabat/pegawai negeri keadaan ini kemudian berubah mengikuti perkembangan jaman, sehingga salah satu isu yang menjatuhkan Orde Lama juga adalah merajalelanya korupsi ke seluruh lapisan masyarakat.

Di Indonesia, korupsi telah menjadi penyakit akut yang sangat sulit untuk diberantas. Bertahun-tahun di bawah pemerintahan yang korup, menjadikan penyebaran korupsi semakin meluas dan sistematis, bahkan korupsi memiliki kecenderungan untuk menjadi masalah publik, yang dilakukan secara bersamasama yang juga disebut dengan "korupsi berjamaah". Korupsi yang meluas dengan mudah dijumpai pada hampir seluruh kantor pelayanan publik. Korupsi telah menjadi bagian sistem pengelolaan negara. Celakanya korupsi sering melibatkan petinggi-petinggi negeri ini. Hasil riset Corruption Perception Index (CPI) pada tahun 2010 skor korupsi untuk Indonesia 9,27 dalam skala $0-10$, di mana 0 berarti sangat bersih, dan 10 sangat korup, turun cukup signifikan dari skor tahun sebelumnya, yaitu 8,32 . Hal ini memberikan arahan bahwa korupsi di Indonesia meningkat dari waktu ke waktu, baik kuantitas maupun kualitas, bahkan korupsi menjadi kejahatan yang sangat luar biasa (extra ordinary crimes), seiring dengan predikat Indonesia sebagai negara terkorup.

Melihat begitu banyaknya aturanaturan maupun pembentukan tim dalam upaya memberantas korupsi, Klitgaard menyatakan bahwa strategi pemberantasan korupsi harus meninggalkan refleks membuat aturan-aturan baru, membuat prosedur baru, dan membentuk unit-unit pengawas baru setiap kali muncul masalah korupsi. Apa yang dinyatakan Klitgaard adalah sesuai dengan fenomena yang terjadi di negeri ini, di mana setiap kali pergantian rezim berkuasa selalu ditandai dengan keseriusan membuat dan mengubah undang-undang tindak pidana korupsi dan memperbanyak lembaga pengawasan atau komisi anti korupsi, meskipun diketahui hasilnya belum efektif dan efisien.

Sejarah pemberantasan korupsi di NKRI telah dimulai sejak tahun 1967, dengan dibentuknya Tim Pemberantasan Korupsi. Pada tahun 1970 dibentuk Komite Anti Korupsi (KAK). Selanjutnya dibentuk juga Komisi Empat. Tahun 1977 dibentuklah Opstib (Operasi Tertib). Kemudian pada tahun 1982 Tim Pemberantas Korupsi (TPK) dihidupkan kembali. Tahun 1999 dibentuk tim yang bertugas untuk memeriksa kekayaan pejabat negara yaitu KPKKN. Selanjutnya dibentuk Tim Gabungan Pemberantasan Tindak Pidana Korupsi (TGPTPK) Tahun 1999. Pada tahun 2002 terbentuklah Komisi Pemberantasan Korupsi (KPK).

Di dalam peraturan perundangundangan, istilah korupsi sebagai istilah yuridis baru digunakan pada tahun 1957, yaitu dengan adanya Peraturan Penguasa Militer yang berlaku di daerah kekuasaan Angkatan Darat, kemudian disusul Undang-Undang Nomor 24/Prp/Tahun 1960 tentang Pengusutan, Penuntutan, dan 
Pemeriksaan Tindak Pidana Korupsi, kemudian digantikan Undang-Undang Nomor 3 Tahun 1971. Selanjutnya berlakulah Undang-Undang Nomor 31 Tahun 1999 tentang Pemberantasan Tindak Pidana Korupsi, kemudian diubah melalui Undang-Undang Nomor 20 Tahun 2001 tentang Perubahan Atas Undang-Undang Nomor 31 Tahun 1999 tentang Pemberantasan Tindak Pidana Korupsi.

Pemerintah Indonesia telah melakukan terobosan dengan memaksimal kan hukuman bagi koruptor yang tertuang dalam Pasal 2 Ayat (2) Undang-Undang Nomor 31 Tahun 1999 yang diubah dengan Undang-Undang Nomor 20 Tahun 2001 tentang Pemberantasan Tindak Pidana Korupsi, di mana dalam salah satu pasal ini sanksi hukumannya adalah hukuman mati, bilamana korupsi dilakukan dalam keadaan tertentu. Dalam "keadaan tertentu" yang dimaksud ketentuan ini adalah keadaan yang dapat dijadikan alasan pemberatan pidana bagi pelaku tindak pidana korupsi yaitu apabila tindak pidana tersebut dilakukan terhadap dana-dana yang diperuntukkan bagi penanggulangan keadaan bahaya, bencana alam nasional, penanggulangan akibat kerusuhan sosial yang meluas, penanggulangan krisis ekonomi dan moneter, dan pengulangan tindak pidana korupsi.

Terobosan yang lain adalah ketika dikenakannya ancaman pidana seumur hidup bagi pelaku tindak pidana gratifikasi, sebagaimana diakomodir dalam Pasal 12B ayat (2) Undang-Undang Nomor 20 Tahun 2001 tentang Pemberantasan Tindak Pidana Korupsi. Di dalam Penjelasan Pasal 12B UU Pemberantasan Tipikor, gratifikasi diberikan makna sebagai pemberian dalam arti luas, yakni meliputi pemberian uang, barang, rabat (discount), komisi, pinjaman tanpa bunga, tiket perjalanan, fasilitas penginapan, perjalanan wisata, pengobatan cuma-cuma, dan fasilitas lainnya. Gratifikasi tersebut baik yang diterima di dalam negeri maupun di luar negeri dan yang dilakukan dengan menggunakan sarana elektronik atau tanpa sarana elektronik. Secara etimologi yang dimaksud dengan gratifikasi adalah berasal dari Bahasa Belanda, "Gratificatie", atau bahasa Inggrisnya "Gratification" yang diartikan hadiah uang. Menurut Kamus Besar Bahasa Indonesia (1998) gratifikasi diartikan pemberian hadiah uang kepada pegawai di luar gaji yang telah ditentukan. Menurut Undang-Undang Nomor 20 Tahun 2001 tentang Pemberantasan Tindak Pidana Korupsi, Penjelasan Pasal 12 b ayat (1), Gratifikasi adalah pemberian dalam arti luas, yakni meliputi pemberian uang, barang, rabat (discount), komisi, pinjaman tanpa bunga, tiket perjalanan, fasilitas penginapan, perjalanan wisata, pengobatan cuma-cuma, dan fasilitas lainnya. Gratifikasi tersebut baik yang diterima di dalam negeri maupun di luar negeri dan yang dilakukan dengan menggunakan sarana elektronik atau tanpa sarana elektronik.

Pemberian gratifikasi tersebut umumnya banyak memanfaatkan momenmomen ataupun peristawa-peristiwa yang cukup baik, seperti pada hari-hari besar keagamaan (hadiah hari raya tertentu), hadiah perkawinan, hari ulang tahun, keuntungan bisnis, dan pengaruh jabatan. Dengan berdalih "sekedar bantuan", "ikhlas", "tanpa pamrih", "rasa simpatik", dan lain-lain, gratifikasi ini memang sangat mudah untuk disamarkan dan dibalut cantik dengan hal-hal demikian, hingga pada akhirnya terucap kata "terima kasih karena sudah dibantu".

Mengingat begitu tersamarnya kasus gratifikasi sebagai sebuah tindak pidana, maka dengan diakomodirnya gratifikasi dalam Undang-Undang Nomor 20 Tahun 2001 tentang Pemberantasan Tipikor hal tersebut memperlihatkan keseriusan pemerintah dan Dewan Perwakilan Rakyat (DPR) dalam memberantas korupsi. Diancamkannya sanksi pidana seumur atau pidana paling 
lama 20 tahun diharapkan dapat dijadikan sebagai shock therapy atau untuk "menakut-nakuti" bagi para calon koruptor lainnya. Sejak dimasukkannya gratifikasi dalam Undang-Undang Nomor 20 Tahun 2001 tentang Pemberantasan Tindak Pidana Korupsi, Pasal 12, sudah banyak kasus di mana pelaku tindak pidana korupsi dijatuhi sanksi yang cukup berat. Beberapa pertanyaan dalam penelitian ini, antara lain:

1. Bagaimanakah pengaturan gratifikasi dalam Undang-Undang Nomor 20 Tahun 2001 tentang Pemberantasan Tindak Pidana Korupsi?

2. Bagaimanakah penegakan hukum tindak pidana korupsi berupa penerimaan gratifikasi sebagai suap?

\section{Pembahasan}

\section{Pengaturan Gratifikasi dalam Undang-Undang Nomor 20 Tahun 2001 tentang Pemberantasan Tindak Pidana Korupsi}

Di Indonesia, gratifikasi sebagai mana tindak pidana korupsi sudah merupakan virus yang menyebar ke seluruh tubuh pemerintahan dimulai dari lembaga terendah sampai lembaga tertinggi sehingga langkah-langkah pemberantasan nya pun masih tersendat-sendat sampai saat ini.

Berkaitan dengan perkembangan gratifikasi yang semakin cepat, kebijakan formulasi dalam upaya menanggulangi tindak pidana korupsi di Indonesia sesungguhnya telah mengalami berbagai perubahan. Bahkan menurut beberapa ahli atau pakar hukum pidana sebagaimana yang telah diuraikan dalam Bab II korupsi digambarkan sebagai suatu penyakit yang dalam perkembangannya bukan saja merusak atau merugikan keuangan dan perekonomian negara, akan tetapi telah melampaui batas-batas tersebut yakni merusak atau merugikan perekonomian rakyat.
Perkembangan gratifikasi terutama dalam lingkup penyelewengan kekuasaan dan suap telah begitu menguasai setiap sendi kehidupan masyarakat, yang pada akhirnya setiap masyarakat dihadapkan pada kesulitan-kesulitan manakala berhadapan dengan para pejabat negara yang seharusnya dapat melayani setiap kebutuhan masyarakat tanpa harus membayar pada pejabat-pejabat tersebut.

Kondisi-kondisi semacam inilah yang kemudian menyebabkan kebijakan hukum pidana khususnya mengenai tindak pidana korupsi mengalami perkembanganperkembangan, yang menggambarkan langkah-langkah ke arah kriminalisasi dan dekriminalisasi.

Perubahan-perubahan kebijakan hukum pidana dalam penanggulangan tindak pidana gratifikasi yang merupakan salah satu wujud dari tindak pidana korupsi, disebabkan oleh perkembangan korupsi yang demikian cepat dan disesuaikan dengan kebutuhan masyarakat guna peningkatan kesejahteraan masyarakat dilukiskan pada konsiderans beberapa perundang-undangan mengenai pem berantasan tindak pidana gratifikasi.

Pertimbangan mengenai perlunya perumusan tindak pidana gratifikasi, sebagaimana diungkapkan dalam konsideran dalam perundang-undangan di atas menunjukkan adanya keprihatinan atas tindak pidana korupsi yang telah merugikan keuangan negara dan menghambat pembangunan nasional.

Pemberian gratifikasi tersebut umumnya banyak memanfaatkan momenmomen ataupun peristawa-peristiwa yang cukup baik, seperti pada hari-hari besar keagamaan (hadiah hari raya tertentu), hadiah perkawinan, hari ulang tahun, keuntungan bisnis, dan pengaruh jabatan. Dengan berdalih "sekedar bantuan", "ikhlas", "tanpa pamrih", "rasa simpatik", dan lain-lain, gratifikasi ini memang sangat mudah untuk disamarkan dan dibalut manis 
dengan hal-hal demikian, sehingga pada akhirnya terucap kata "terima kasih karena sudah dibantu".

Dalam penjelasan Undang-Undang Nomor 20 Tahun 2001 disebutkan bahwa Sejak Undang-undang Nomor 31 Tahun 1999 tentang Pemberantasan Tindak Pidana Korupsi (Lembaran Negara Republik Indonesia Tahun 1999 Nomor 140, Tambahan Lembaran Negara Republik Indonesia Nomor 3874) diundangkan, terdapat berbagai interpretasi atau penafsiran yang berkembang di masyarakat khususnya mengenai penerapan Undangundang tersebut terhadap tindak pidana korupsi yang terjadi sebelum Undangundang Nomor 31 Tahun 1999 diundangkan.

Di samping hal tersebut, mengingat korupsi di Indonesia terjadi secara sistematik dan meluas sehingga tidak hanya merugikan keuangan negara, tetapi juga telah melanggar hak-hak sosial dan ekonomi masyarakat secara luas, maka pemberantasan korupsi perlu dilakukan dengan cara luar biasa. Dengan demikian, pemberantasan tindak pidana korupsi harus dilakukan dengan cara yang khusus, antara lain penerapan sistem pembuktian terbalik yakni pembuktian yang dibebankan kepada terdakwa. Untuk mencapai kepastian hukum, menghilangkan keragaman penafsiran, dan perlakuan adil dalam memberantas tindak pidana korupsi, perlu diadakan perubahan atas Undang-undang Nomor 31 Tahun 1999 tentang Pemberantasan Tindak Pidana Korupsi.

Ketentuan perluasan mengenai sumber perolehan alat bukti yang sah yang berupa petunjuk, dirumuskan bahwa mengenai "petunjuk" selain diperoleh dari keterangan saksi, surat, dan keterangan terdakwa, juga diperoleh dari alat bukti lain yang berupa informasi yang diucapkan, dikirim, diterima, atau disimpan secara elektronik dengan alat optik atau yang serupa dengan itu tetapi tidak terbatas pada data penghubung elektronik (electronic data interchange), surat elektronik (e-mail), telegram, teleks, dan faksimili, dan dari dokumen, yakni setiap rekaman data atau informasi yang dapat dilihat, dibaca dan atau didengar yang dapat dikeluarkan dengan atau tanpa bantuan suatu sarana, baik yang tertuang di atas kertas, benda fisik apapun selain kertas, maupun yang terekam secara elektronik, yang berupa tulisan, suara, gambar, peta, rancangan, foto, huruf, tanda, angka, atau perforasi yang memiliki makna.

Ketentuan mengenai "pembuktian terbalik" perlu ditambahkan dalam Undang-undang Nomor 31 Tahun 1999 tentang Pemberantasan Tindak Pidana Korupsi sebagai ketentuan yang bersifat "premium remidium" dan sekaligus mengandung sifat prevensi khusus terhadap pegawai negeri sebagaimana dimaksud dalam Pasal 1 angka 2 atau terhadap penyelenggara negara sebagaimana dimaksud dalam Pasal 2 Undang-undang Nomor 28 Tahun 1999 tentang Penyelenggara Negara yang Bersih dan Bebas dari Korupsi, Kolusi, dan Nepotisme, untuk tidak melakukan tindak pidana korupsi.

\section{Penegakan Hukum Tipikor berupa Penerimaan Gratifikasi sebagai Suap}

Penuntutan adalah tindakan penuntut umum untuk melimpahkan perkara pidana ke pengadilan negeri yang berwenang dalam hal dan menurut cara yang diatur dalam undang-undang dengan permintaan supaya diperiksa dan diputus oleh hakim di sidang pengadilan. Setelah perkara dimasukkan persidangan, maka tugas hakim untuk memutus berdasarkan hasil persidangan yang diyakininya. Hakim sebagai penegak hukum, menjalankan tugas yakni memutus perkara yang diajukan kepadanya tidak boleh lepas dari apa yang diamanatkan oleh UndangUndang. 
Untuk memberikan penjelasan mengenai permasalahan ke 2 (dua) penulisan hukum ini, penulis memberikan contoh kasus yang berkaitan dengan permasalahan yang penulis angkat. Kasus ini diputus di Pengadilan Negeri Semarang dengan No. Putusan No.43/Pid.Sus /2012/PN.Tip.Smg.

Atas perintah AZ melalui AYM tersebut, SKPD PSDA menyanggupi menyediakan uang sebesar Rp.200.000.000 (dua ratus juta rupiah), dan SKPD Bina Marga menyanggupi menyedia kan uang sebesar Rp. 150.000.000,- (seratus lima puluh juta rupiah)", sehingga berjumlah Rp. 350.000 .000 ,- (tiga ratus lima puluh juta rupiah), kemudian kesanggupan SKPD PSDA dan SKPD Bina Marga tersebut dilaporkan AYM kepada AZ, lalu AZ mengatakan "Ya sudah dikumpulkan saja ke bendaharawanmu".

Pada tanggal 10 Nopember 2011, bertempat di ruang rapat VIP Kantor Walikota, dilakukan pertemuan antara A Z Drs. H. S HS, M.Si dengan Pimpinan Dewan: A, J dan $\mathrm{S}$ dengan dihadiri oleh AYM, di mana Drs. H.S HS, M.Si menyampaikan bahwa sudah bertemu dengan Terdakwa APS dan sudah bersepakat bahwa partai akan membantu melaksanakan pembahasan RAPBD Tahun Angaran 2012 menjadi APBD Tahun 2012, nanti akan ada bantuan atau atensi dari Pemerintah Kota Semarang untuk anggota DPRD Kota Semarang sebesar Rp. 4.000.000.000,-(empat milyar rupiah).

Selanjutnya AZ merealisasikan permintaan anggota DPRD Kota Semarang melalui Terdakwa Agung Purno Sarjono dengan memerintahkan AYM meng hubungi Terdakwa APS dan S untuk datang ke ruang kerja Sekda guna mengambil uang yang telah disediakan AZ.

Pada sore harinya, Terdakwa APS bersama-sama $\mathrm{S}$ datang menemui $\mathrm{AZ}$, lalu AZ memanggil stafnya $\mathrm{H}$ alias $\mathrm{N}$ dan memerintahkannya untuk membawa tas berisi uang yang telah disiapkan $\mathrm{AZ}$ untuk diberikan kepada anggota DPRD Kota. Selanjutnya $\mathrm{H}$ alias $\mathrm{N}$ menyerahkan tas berisi uang tersebut kepada AZ, lalu oleh A $\mathrm{Z}$ atas berisi uang tersebut langsung diberikannya kepada terdakwa APS dan S sambil mengatakan bahwa uang tersebut untuk Dewan, per anggota DPRD di fraksinya mendapat Rp. 8.000.000,(delapan juta rupiah). Setelah menerima uang dari AZ, kemudian Terdakwa AGP dengan disaksikan $\mathrm{S}$ menyampaikan kepada $A Z$ "Ini masih kurang pak?" dan dijawab $A Z$ "Keuangannya sementara adanya itu dulu Pak".

Beberapa saat kemudian, datang juga AP dan S. Selanjutnya AZ memanggil $\mathrm{H}$ alias $\mathrm{N}$ untuk membawa uang, lalu uang tersebut langsung diberikannya kepada APS dan S, sehingga perincian total uang yang diberikan $A Z$ kepada Terdakwa APS dan S, AP dan S.

Berkaitan dengan tugas Jaksa sebagai penuntut umum dan Hakim dalam suatu peradilan, maka jaksa mempunyai peran sentral. Adapun tugas dan wewenang kejaksaan tidak hanya pidana khusus (tindak pidana korupsi), tetapi juga menangani pidana umum yang lain, hal ini terdapat dalam Undang-Undang Nomor 16 Tahun 2004 Pasal 30. Untuk melengkapi berkas perkara pemeriksaan tambahan dilakukan dengan memperhatikan hal-hal sebagai berikut:

a. Tidak dilakukan terhadap tersangka;

b. Hanya terdapat perkara-perkara yang sulit pembuktiannya, dan atau dapat meresahkan masyarakat, dan atau yang dapat membahayakan keselamatan Negara;

c. Harus dapat diselesaikan dalam waktu 14 (Empat belas) hari setelah dilaksanakan ketentuan Pasal 110 ayat 4 dan 138 Undang-Undang Nomor 8 Tahun 1981 tentang Hukum Acara Pidana;

d. Prinsip koordinasi dan kerjasama dengan penyidik.

e. Di bidang perdata dan tata usaha negara, 
kejaksaan dengan kuasa khusus dapat bertindak baik di dalam maupun di luar pengadilan untuk dan atas nama negara atau pemerintah.

Menurut Pasal 31 Undang-Undang No. 16 Tahun 2004, Kejaksaan dapat meminta kepada hakim untuk menempat kan seorang terdakwa di rumah sakit, tempat perawatan jiwa, atau tempat lain yang layak karena yang bersangkutan tidak mampu berdiri sendiri atau disebabkan oleh hal-hal yang dapat membahayakan orang lain, lingkungan, atau dirinya sendiri. Di samping tugas dan wewenang tersebut, kejaksaan dapat diserahi tugas dan wewenang lain berdasarkan UndangUndang sebagaimana diatur dalam Pasal 32 Undang-Undang Nomor 16 Tahun 2004.

Selanjutnya tugas hakim dalam proses peradilan yaitu memutus suatu perkara yang diajukan kepadanya. Sebagimana diatur dalam Undang-Undang Pokok Kekuasaan Kehakiman, bahwa hakim wajib memutus setiap perkara apabila unsur-unsur suatu tindak pidana yang diajukan terpenuhi. Hakim dalam memutus perkara berdasar pada proses pembuktian di dalam persidangan.

Memahami kasus APS tersebut di atas, bahwa terdakwa terbukti dan secara sah melakukan tindak pidana gratifikasi sebagaimana diatur dalam Pasal 12 ayat (1). Akan tetapi hakim berpandangan lain, yakni lebih memilih memutus terdakwa berdasarkan apa yang didakwakan oleh JPU daripada tuntutan yang dituntutkan oleh JPU. Hal ini dapat penulis pahami bahwa, berdasarkan penjelasan pertanyaan 1 (Satu) di atas, yakni adanya kelemahan dari kebijakan formulasi Undang-Undang Pemberantasan Tindak Pidana Korupsi khususnya sanksi pidana mati Pasal 2 ayat (2). Oleh karena itu, berdasarkan kasus ini penulis menyimpulkan bahwa penerapan sanksi pidana mati dalam UUPTPK belum dapat dilaksanakan karena adanya kelemahan dalam kebijakan formulasi sanksi pidana mati tersebut, sehingga sampai saat ini tidak ada satu pun koruptor yang dijatuhi pidana mati walaupun telah memenuhi rumusan Pasal 2 ayat 2 UUPTPK tersebut.

Selain melakukan analisis terhadap kasus APS di atas, kasus-kasus korupsi yang lain juga memperlihatkan aplikasi yang masih lemah sehingga dinilai belum optimal dalam rangka penegakan hukum atas tindak pidana korupsi di negeri ini yang semakin merajalela. Lemahnya aplikasi tersebut disebabkan oleh faktor, seperti; kurangnya kurangnya koordinasi antara pihak-pihak yang terkait, kurangnya penguasan materi oleh jaksa dalam proses penuntutan dalam tindak pidana korupsi khususnya Pasal 2 ayat (2) yaitu tentang ancaman sanksi pidana mati, di samping secara substansial karena kurang menggigit nya atau kelemahan dari kebijakan formulasi dari Undang-Undang No. 31 Tahun 1999 tentang Pemberantasan Tindak Pidana Korupsi, sehingga jaksa penuntut umum ragu-ragu dalam menjalankan tugasnya.

\section{Kesimpulan}

Dari uraian sebelumnya, maka kesimpulan yang diambil adalah:

1. Pengaturan tindak pidana gratifikasi yang semakin marak di negeri ini sudah diatur dalam Undang-Undang Nomor 20 Tahun 2001 tentang Pemberantasan Tindak Pidana Korupsi dengan ancaman dan sanksi maksimal pidana seumur hidup dan denda sebesar 1 milyar rupiah, dinilai masih kurang serius, kurang faktual, serta bersifat masih limitatif, di mana syarat agar bisa dijatuhkannya sanksi maksimal pada pelaku tindak pidana gratifikasi yang terbukti oleh pengadilan dipandang sulit untuk dipenuhi, karena hanya didasarkan hanya pada kondisi terjadinya suatu momentum. Padahal dengan berpatokan pada Keputusan Ketua Mahkamah Agung Republik 
Indonesia Nomor 191/KMA/SK/XII/ 2010 tanggal 01 Desember 2010, maka ancaman pidana seumur hidup dalam Undang-Undang Nomor 20 Tahun 2001 secara otomatis juga dapat diterapkan.

2. Penegakan hukum terhadap ketentuan suap dan gratifikasi di Indonesia sejauh ini masih relatif rendah, walaupun Indonesia telah memiliki perangkat penegakan anti gratifikasi selama ini. Namun implementasi ketentuan ini masih akan menghadapi beberapa hambatan baik dari sisi peraturan, penegakan, maupun cara pandang masyarakat terhadap tindak pidana pencucian uang. Apabila dilihat dari sudut substansi masih terdapat celah

\section{Saran}

Perumusan kebijakan formulasi sanksi pidana mati ke depannya dalam bentuk undang-undang, seharusnya melibatkan aspek-aspek tersebut sebagai rujukan perumusan, seperti; 1) Budaya feodal dan paternalis yang menjadi kultur bangsa Indonesia menciptakan pengawasan yang lemah, sehingga fungsi auditing dan controlling yang seharusnya menjelma dalam setiap instansi birokrasi kurang menunjukkan peranan optimal, 2) Korupsi sudah menjadi budaya, seiring dengan merebaknya dekadensi moral bangsa Indonesia di hampir semua sektor kehidupan masyarakat, sehingga terjadi reduksi nilai-nilai kebenaran di masyarakat. Suap, upeti serta pungli secara normatif sudah menjadi "makanan khas" setiap hati bangsa Indonesia, sehingga secara sosiologis sangat membantu skala korupsi di negeri ini. 3) Lemahnya penegakan hukum atau yang sering disebut sebagai belum adanya supremasi hukum di negeri ini bisa dikatakan sebagai salah satu kambing hitam merebaknya korupsi. Aparat penegak hukum yang seharusnya mampu berperan sebagai "sapu" kotoran sosial, bahkan dalam beberapa kesempatan justru malah ikut-ikutan bermain dalam kubangan kotoran. Hal tersebut lebih diperburuk dengan lemahnya goodwill eksekutif dan legislatif dalam membentuk suatu pemerintah yang bersih dari korupsi.

\section{Daftar Pustaka}

Arief, Barda Nawawi, Bunga Rampai Kebijakan Hukum Pidana (Perkembangan Penyusunan KUHP Baru), (Jakarta: Kencana Prenada Media Group, 2010).

Arief, Barda Nawawi. Kebijakan Formulasi Ketentuan Pidana dalam Peraturan Perundang-undangan. (Semarang: Pustaka MagisterElangtuo Kinasih, 2012).

Arief, Barda Nawawi. Sari Kuliah Hukum Pidana II. (Semarang: Badan Penyedia Kuliah Fakultas Universitas Diponegoro, 1984).

Ariman, H. M. Rasyid. Sanksi Pidana dan Pemidanaan dalam Undang-Undang Tindak Pidana Korupsi (Jakarta: Kiara Wacana, 2006).

Atmasasmita, Romli. Sekitar Masalah Korupsi Aspek Nasional dan Aspek Internasional, (Bandung: Mandar Maju, 2004).

Garnasih, Yenti. Anti "Gratifikasi Sebagai Strategi untuk Memberantas Kejahatan Keuangan (Profit Oriented Crimes)", Jurnal Hukum Progresif, PDIH Universitas Diponegoro, Semarang, 2006.

Hartanti, Evi. Tindak Pidana Korupsi. (Jakarta: Sinar Grafika, 2005).

Kartanegara, Satochid. Hukum Pidana Bagian Satu, (Jakarta: Balai Lektur Mahasiswa, 1998).

Kartanegara, Satochid. Kumpulan Catatan Kuliah Hukum Pidana II, disusun oleh Mahasiswa PTIK Angkatan V, Tahun 1954-1955. 